University of Nebraska - Lincoln

DigitalCommons@University of Nebraska - Lincoln

\title{
Degree of woody encroachment into grasslands controls soil carbohydrate and amino compound changes during long term laboratory incubation
}

\author{
Courtney A. Creamer \\ Purdue University, courtneycreamer@gmail.com \\ Timothy R. Filley \\ Purdue University \\ Dan C. Olk \\ USDA-ARS \\ Alain Plante \\ University of Pennsylvania \\ Clément Peltre \\ University of Pennsylvania \\ See next page for additional authors
}

Follow this and additional works at: https://digitalcommons.unl.edu/usdaarsfacpub

Creamer, Courtney A.; Filley, Timothy R.; Olk, Dan C.; Plante, Alain; Peltre, Clément; Top, Sara M.; and Boutton, Thomas W., "Degree of woody encroachment into grasslands controls soil carbohydrate and amino compound changes during long term laboratory incubation" (2012). Publications from USDA-ARS / UNL Faculty. 1148.

https://digitalcommons.unl.edu/usdaarsfacpub/1148

This Article is brought to you for free and open access by the U.S. Department of Agriculture: Agricultural Research Service, Lincoln, Nebraska at DigitalCommons@University of Nebraska - Lincoln. It has been accepted for inclusion in Publications from USDA-ARS / UNL Faculty by an authorized administrator of DigitalCommons@University of Nebraska - Lincoln. 


\section{Authors}

Courtney A. Creamer, Timothy R. Filley, Dan C. Olk, Alain Plante, Clément Peltre, Sara M. Top, and Thomas W. Boutton 


\title{
Degree of woody encroachment into grasslands controls soil carbohydrate and amino compound changes during long term laboratory incubation
}

\author{
Courtney A. Creamer ${ }^{\mathrm{a}, \mathrm{b}, *}$, Timothy R. Filley ${ }^{\mathrm{a}, \mathrm{b}}$, Dan C. Olk ${ }^{\mathrm{c}}$, Alain Plante ${ }^{\mathrm{d}}$, Clément Peltre ${ }^{\mathrm{d}}$, Sara M. Top ${ }^{\mathrm{a}, \mathrm{b}}$, \\ Thomas W. Boutton ${ }^{\mathrm{e}}$ \\ a Department of Earth and Atmospheric Sciences, Purdue University, West Lafayette, IN 47907, USA \\ ${ }^{\mathrm{b}}$ Purdue Climate Change Research Center, West Lafayette, IN 47907, USA \\ ${ }^{c}$ USDA-ARS, National Laboratory for Agriculture and the Environment, Ames, IA 50011, USA \\ d Department of Earth and Environmental Science, University of Pennsylvania, Philadelphia, PA 19104-6316, USA \\ ${ }^{\mathrm{e}}$ Department of Ecosystem Science and Management, Texas AE'M University, College Station, TX 77843, USA
}

\section{A R T I C L E I N F O}

Article history:

Received 4 March 2012

Received in revised form 2 July 2012

Accepted 6 August 2012

Available online 14 August 2012

\begin{abstract}
A B S T R A C T
Up to $50 \%$ of organic $C$ and $80 \%$ of organic $N$ within soil can exist as amino acids, amino sugars and carbohydrates. To determine how potential microbial accessibility and turnover of these compounds is impacted by encroachment of woody plants into grasslands, we investigated changes in evolved $\mathrm{CO}_{2}$ during thermal analysis and in carbohydrate and amino compound chemistry after long term laboratory incubation of sandy loam grassland woodland soils from southern Texas, USA. Thermal analysis showed that incubation increased the amount of soil organic matter (SOM) released at higher temperatures and that evolved $\mathrm{CO}_{2}$ profiles correlated with increases in amino $\mathrm{C}$. During incubation, total carbohydrate $\mathrm{C}$ decreased slightly faster than bulk soil $\mathrm{C}$, with preferential loss of plant-derived carbohydrates and/or production of microbial carbohydrates most strongly expressed in grassland and younger woodland soils. Total $\mathrm{N}$ content did not change during incubation, so the reduction in extractable amino $\mathrm{N}$ in older woodland soils suggested that $\mathrm{N}$ became more resistant to extraction during incubation. These data, along with previous measurements of respired $\mathrm{CO}_{2}$, indicate that changes in carbohydrate $\mathrm{C}$ and amino $\mathrm{C}$ did not predict mineralized $\mathrm{CO}_{2}$ yields and that amino compounds and microbial carbohydrate $\mathrm{C}$ were not selectively lost during incubation. The differing response in SOM loss (or enrichment) during incubation of the older woodland soils revealed a system with altered SOM dynamics due to woody encroachment, confirming that the short term 'lability' or 'recalcitrance' of SOM components is dependent on a number of interacting variables.
\end{abstract}

(C) 2012 Elsevier Ltd. All rights reserved.

\section{Introduction}

Woody plant encroachment into grass-dominated ecosystems is a globally extensive land cover change that has been occurring at a rapid rate over the past 100-200 years (Maestre et al., 2009; Van Auken, 2009; Barger et al., 2011; Eldridge et al., 2011). The phenomenon appears to be driven by a number of factors, including livestock grazing (Roques et al., 2001), reduced fire frequency (Scholes and Archer, 1997), changes in atmospheric N deposition (Köchy and Wilson, 2001), rising atmospheric $\mathrm{CO}_{2}$ concentration (Polley et al., 1994; Bond and Midgley, 2000), and climate change (Knapp et al., 2008).

In the Rio Grande Plains region of southern Texas, woody plant assemblages dominated by $\mathrm{N}$-fixing woody plants are encroaching into areas that were once open grassland (Archer et al., 1988;

\footnotetext{
* Corresponding author. Present address: CSIRO Land and Water, Adelaide, Australia. Tel.: +1 4403642147 .

E-mail address: courtneycreamer@gmail.com (C.A. Creamer).
}

Archer, 1995; Boutton et al., 1998). Following woody plant invasion in southern Texas, above and below ground primary productivity increase as soil C and $\mathrm{N}$ accumulate (Boutton et al., 1999; Liao et al., 2006b; Boutton and Liao, 2010), predominantly in more physically unprotected free light and particulate organic matter (POM) fractions (Liao et al., 2006a, 2006b). The amount of $C$ held within the more physically unprotected free light and macroaggregate sized fractions increases from ca. $28 \%$ of total soil C in grassland soils to ca. $61 \%$ of total soil $\mathrm{C}$ in woodland soils after 40 years of woody stand development (Liao et al., 2006a, 2006b; Creamer et al., 2011). Soil OM (SOM) under the encroaching woody stands also reflects the changing plant input chemistry, with a buildup of woodland-derived lignin and aliphatic biopolymers in non-mineral bound soil fractions (Filley et al., 2008). Long term incubation of these soil samples indicated that the potential for $\mathrm{C}$ degradation was altered by woody stand establishment, with soil samples from older woody tree clusters (34-86 years) respiring a significantly greater proportion of soil organic carbon (SOC; $17 \pm 3 \%$ ) after 1 year of incubation than recently established, 
younger woody tree clusters (14-23 years) and the remnant grassland ( $11 \pm 2 \%$ and $9 \pm 3 \%$ of SOC, respectively; Creamer et al., 2011). Stable carbon isotope evidence gathered from $\mathrm{CO}_{2}$ respired during the incubation was unable to identify precisely the $C$ sources which contributed to greater SOC loss from older woody clusters, although the data did suggest that after the initial few weeks, newer ( $C_{3}$ woodland derived) and physically accessible $C$ in the free light and macroaggregate sized fractions was respired preferentially from the older woody clusters due to an increase in the proportions of whole soil $\mathrm{C}$ held within these fractions.

SOM is a complex mixture of plant and microbial biopolymers at various stages of alteration, and preservation or accrual can result from a number of different stabilization mechanisms (Baldock and Skjemstad, 2000). Several approaches, such as soil incubation, chemical extraction, soil fractionation, thermal analyses, and spectroscopic methods, have been developed to assess the relative stability and composition of SOM with the aim of finding a rapid, consistent and quantitative index for determining the mean residence time of SOM across a wide range of environmental conditions (Kögel-Knabner, 2000; von Lützow et al., 2007; Plante et al., 2009). However, the turnover of SOM is dependent on a wide array of factors, which are often difficult to separate and are related to the properties of different ecosystems (Schmidt et al., 2011).

Organic geochemical perspectives of the potential "lability" of SOM usually focus on the relative proportions of holocellulose, lignin, and amino compounds within different fractions (Poirier et al., 2005). Cellulose and hemicelluose are important for SOM cycling as they are the most abundant plant biopolymers (Kögel-Knabner, 2002), are generally considered to be easily hydrolyzed by microorganisms, and may represent $10-30 \%$ of SOC (Guggenberger et al., 1994; Martens et al., 2004; Derrien et al., 2006) although values as high as $50 \%$ have been reported. Amino sugars and amino acids (AAs) can account for up to $15-20 \%$ of SOC (Martens et al., 2004) but, more importantly, have been shown to comprise between $30 \%$ and $80 \%$ of total soil N (Knicker et al., 1993; Amelung et al., 2001; Martens et al., 2006; Olk et al., 2008). As these compounds represent potentially important sources of $\mathrm{C}$ and $\mathrm{N}$ for microorganisms, their input rate and turnover can affect the rate of $\mathrm{C}$ and $\mathrm{N}$ cycling and help facilitate or prevent SOM accrual (Fontaine et al., 2004).

Thermal analysis uses a different perspective from chemical extraction to gain insight into the makeup of soil. It has recently been used to link thermal stability with the biological and chemical stability of SOM and, as such, may be able to provide a broader picture of SOM composition (Grisi et al., 1998; Plante et al., 2009, 2011). However, the degree and nature of mineral-OM interaction is often a difficult analytical challenge that interferes with the ability to compare potentially complementary tools used to assess SOM stability, such as thermal analysis and wet chemical extraction. The soils examined here, with low clay contents $(<10 \%)$ and low proportions of whole soil $\mathrm{C}$ held on free silt and clay particles in the grassland (ca. 30\%) and woodland (5-16\%), allow utilization of different methods for assessing SOM stability (laboratory incubation, thermal analysis, wet chemical extraction) with minimal impact from soil minerals.

The purpose of this study was to document changes in SOM composition during incubation of sandy loam soils with different proportions of grass and woody tissues. Our objective was to determine if degradation of amino compounds and carbohydrates was responsible for the unexpectedly high proportion of SOC lost from older cluster soils relative to younger cluster and grassland soils during a previous laboratory incubation (Creamer et al., 2011). We used thermal analysis as a preliminary means of assessing overall changes in SOM as a result of incubation and then determined changes in relative concentrations of individual carbohydrate and amino compounds to examine whether or not specific compounds were preserved or degraded during the incubation in response to changing OM input following woody plant encroachment.

\section{Material and methods}

\subsection{Site description, and soil sampling and incubation}

Soil samples were from the Texas AgriLife La Copita Research Area in the Rio Grande Plains of southern Texas (Blair, 1950). In this region, fire suppression combined with livestock overgrazing has resulted in progressive encroachment of subtropical $C_{3}$ thorn woodlands into the remnant $\mathrm{C}_{4}$-dominanted grassland over the past 150 years (Archer, 1990; McLendon, 1993; Boutton et al., 1998). After initial establishment of the $\mathrm{N}$-fixing Prosopis glandulosa (honey mesquite), other shrub/tree species, such as Zanthoxylum fagara (lime prickly ash) and Diospyros texana (persimmon), enter the understory and form woody clusters (Archer et al., 1988). Thus, woody clusters are composed of a single mesquite tree with up to 15 other tree/shrub species beneath its canopy. Soils under these woody clusters and the remnant grassland are sandy loams (fine-loamy mixed hyperthermic Typic Argiustolls of the Runge series) with $80 \%$ sand, $10 \%$ silt and $10 \%$ clay. More information on the soils is presented in Table 1 . Mean annual temperature is $22.4^{\circ} \mathrm{C}$ and average annual rainfall $716 \mathrm{~mm}$. For more detailed site descriptions, see Scifres and Koerth (1987), Archer (1995) and Boutton et al. (1998).

Cores were taken from the upper $30 \mathrm{~cm}$ of the mineral soil from 15 woody clusters and 15 grassland patches adjacent to each of the woody clusters in October 2006. For each woody cluster site, four cores (one in each cardinal direction) were taken within $50 \mathrm{~cm}$ of the base of the largest mesquite tree, divided into $10 \mathrm{~cm}$ depth increments, and pooled. From the adjacent grassland, four cores were taken near the base a randomly selected $C_{4}$ plant (one in each cardinal direction). The 15 woody cluster sites ranged in age from 14-86 years and established a chronosequence of woody encroachment. The basal diameter of the mesquite tree in each woody cluster was measured and used in site-specific regression equations developed by Stoker (1997) to determine the age of the tree and therefore the age of the woody cluster. After sampling, the uppermost $10 \mathrm{~cm}$ of the field-moist soil were passed through an $8 \mathrm{~mm}$ sieve and oven-dried at $50^{\circ} \mathrm{C}$ until constant weight. Ten of these woody cluster soils ( 3 younger woody cluster soils and 7 older woody cluster soils) and their corresponding grassland soils were subjected to a year incubation as described by Creamer et al. (2011). Briefly, $2 \mathrm{mg}$ of soil was mixed in equal weight with ashed quartz sand and incubated at $30^{\circ} \mathrm{C}$ at constant moisture after addition of an inoculum. Respired $\mathrm{CO}_{2}$ was measured periodically, and at the end of the year the samples were oven dried at $50{ }^{\circ} \mathrm{C}$ for 2 days. The dried incubated soil and a sub-sample of each dry unincubated soil were ground to a fine powder using a steel ball mill (Retsch, Haan, Germany). C and N concentrations were determined for the ground soil prior to and after incubation using an elemental analyzer (EA) interfaced to a PDZ Europa 20/20 isotope ratio mass spectrometer (Sercon, Crewe, UK). Prior to and after incubation, celluloses, hemicelluloses, AAs, and amino sugars were extracted from the ground soils from all ten woody cluster soils (3 younger woody cluster sites and 7 older woody cluster sites) and three of the ten grassland soils as described below. Three replicates of the unincubated soils and the three biological replicates of the incubated soils were extracted.

\subsection{Thermal analysis}

Changes in SOM composition were assessed using evolved gas analysis (EGA) of $\mathrm{CO}_{2}\left(\mathrm{CO}_{2} \mathrm{EGA}\right)$ during the thermal analysis 
Table 1

Soil properties. Grasslands represent time 0, while younger clusters are 14-23 years and older clusters 34-86 years.

\begin{tabular}{|c|c|c|c|c|c|c|c|}
\hline & \multirow[t]{2}{*}{$\mathrm{pH}$} & \multirow[t]{2}{*}{$\mathrm{mg} \mathrm{Cg} \mathrm{g}^{-1}$ soil } & \multirow[t]{2}{*}{$\mathrm{mg} \mathrm{N} \mathrm{g}^{-1}$ soil } & \multicolumn{4}{|c|}{ Whole soil carbon (\%) } \\
\hline & & & & FLF $^{\mathrm{a}}$ & Macros $^{\mathrm{b}}$ & Micros $^{\mathrm{c}}$ & Free silt + clay $^{\mathrm{d}}$ \\
\hline Grassland & 7.0 & $5.5 \pm 0.13$ & $0.56 \pm 0.14$ & 11 & 17 & 41 & 31 \\
\hline Young clusters & 7.1 & $8.0 \pm 3.2$ & $0.80 \pm 0.35$ & 18 & 20 & 46 & 16 \\
\hline Old clusters & 6.0 & $18 \pm 2.0$ & $1.59 \pm 0.19$ & 25 & 36 & 34 & 5 \\
\hline
\end{tabular}

${ }^{\text {a }}$ Free light fraction $\left(<1.0 \mathrm{~g} \mathrm{~cm}^{-3}\right)$.

b Macroaggregate fraction $(>250 \mu \mathrm{m})$.

c Microaggregate fraction $(52-250 \mu \mathrm{m})$.

${ }^{\mathrm{d}}$ Free silt and clay fraction $(<53 \mu \mathrm{m})$.

combustion of SOM. Preliminary results showed that patterns of $\mathrm{CO}_{2}$ EGA and differential scanning calorimetry (DSC) were highly correlated, making both well suited to SOM characterization. DSC is strongly affected by the changing heat capacity of the mineral matrix during analysis, so requires significant correction for baseline drift. This is particularly problematic for low SOM samples. Due to the low SOM content of the samples, we elected to use $\mathrm{CO}_{2-}$ EGA data to characterize changes in SOM.

A subset of incubated and unincubated soils taken along the chronosequence was subjected to thermal analysis by heating $30 \mathrm{mg}$ of the soil and sand mixture from 30 to $700^{\circ} \mathrm{C}$ at $10^{\circ} \mathrm{C} \mathrm{min}^{-1}$ (with a $15 \mathrm{~min}$ isothermal stop at $105^{\circ} \mathrm{C}$ to drive off moisture) using a Netzsch STA 409PC Luxx TG-DSC thermal analyzer equipped with a type-S (Pt-Rh) sample carrier (NetzchGerätebau GmbH, Selb, Germany). Samples were held in Pt crucibles, with an empty reference crucible under an oxidizing atmosphere of $30 \mathrm{ml} \mathrm{min}^{-1}$ with synthetic air $\left(20 \% \mathrm{O}_{2}\right.$ and $\mathrm{N}_{2}$ balance) and $10 \mathrm{ml} \mathrm{min}^{-1}$ with $\mathrm{N}_{2}$ as protective gas. $\mathrm{CO}_{2}$ EGA was measured using a $\mathrm{LI}-840 \mathrm{~A} \mathrm{CO} \mathrm{CO}_{2} / \mathrm{H}_{2} \mathrm{O}$ infrared gas analyzer (LI-COR Biosciences, Lincoln, Nebraska) coupled to the thermal analyzer. Due to the low clay content of the soils $(<10 \%)$ and the uniformity of their texture along the chronosequence, differences in $\mathrm{CO}_{2}$ release during thermal analysis should be primarily a result of differences in the degradability and thermal stability of SOM rather than differences in soil mineralogy. This provided an exceptional opportunity to examine, via both thermal analysis and wet chemical extraction, the impact of changing SOM chemistry in response to woody encroachment and microbial decay during incubation.

\subsection{Biochemical analyses}

\subsubsection{Cellulose and hemicellulose}

Monosaccharides derived from cellulose and hemicellulose were extracted and analyzed as described by Martens and Frankenberger (1990) and Martens and Loeffelmann (2002). Briefly, $800 \mu \mathrm{l}$ of $6 \mathrm{M} \mathrm{H}_{2} \mathrm{SO}_{4}$ was added to $100 \mathrm{mg}$ whole soil in a glass culture tube. After mixing, the solution was allowed to sit (30 $\mathrm{min}$ ) at room temperature and then diluted to $1 \mathrm{M} \mathrm{H}_{2} \mathrm{SO}_{4}$. The solution was autoclaved for $30 \mathrm{~min}$ at $121^{\circ} \mathrm{C}$, centrifuged, and the supernatant was removed following quantitative rinsing of the remaining residue with distilled water. This residue was saved and sequentially processed for cellulose (strong-acid extractable carbohydrates) as described below. The supernatant containing the hemicellulose (mild acid-extractable carbohydrates) was adjusted with $\mathrm{NaOH}$ to $\mathrm{pH}$ 5.5-6.5, diluted, and an aliquot was injected into a Dionex (Sunnyvale, CA) DX-500 anion chromatograph equipped with a CarboPac PA-10 column $(2 \mathrm{~mm} \times 250 \mathrm{~mm})$. Carbohydrates were detected using triple-pulse amperometry (Johnson et al., 1993; Olk, 2008). The stronger acid (cellulose) extraction, which isolated hydrolyzed glucose, was performed on the dried residue from the weaker acid extraction using $300 \mu \mathrm{l}$ of $18 \mathrm{M} \mathrm{H}_{2} \mathrm{SO}_{4}$, which was then diluted to $1.5 \mathrm{M}$ after sitting for $30 \mathrm{~min}$.

\subsubsection{AAs and amino sugars}

The extraction and analysis of AAs and amino sugars was identical to the procedure reported by Creamer et al. (2012), and described by Martens and Loeffelmann (2003) and modified by Olk et al. (2008). Briefly, $4 \mathrm{M}$ methanesulfonic acid containing $0.2 \%$ (wt.) tryptamine [3-(2-aminoethyl)indole] was added to $250 \mathrm{mg}$ soil and autoclaved at $136{ }^{\circ} \mathrm{C}$ and $248 \mathrm{kPa}$ for $90 \mathrm{~min}$. The solution was neutralized, diluted, centrifuged and injected into a Dionex (Sunnyvale, CA) DX-500 anion chromatograph equipped with a Dionex AminoPac PA-10 column and detected with triple-pulse amperometry (Johnson et al., 1993; Olk, 2008). With this method, asparagine and glutamine are converted to glutamic acid and aspartic acid, respectively, and cysteine converted to cystine. In addition, tryptophan is not recovered, although the other AAs plus two amino sugars (glucosamine, galactosamine) and two nonessential AAs (hydroxyproline, ornithine) can be identified.

\subsection{Calculations and statistical analysis}

Student t-tests were used to compare measurements of extracted carbohydrates, AAs, and amino sugars before and after incubation. One-way ANOVA was used to test for differences in extracted compounds in response to stand age or landscape element. Natural groupings of respiration data obtained from the incubation, as described by Creamer et al. (2011), justified the grouping of the samples into landscape elements of younger clusters (woody stands 14-23 years), older clusters (woody stands 34-86 years) and grasslands ( 0 years).

Principal component analysis (PCA) was performed on $\mathrm{CO}_{2}$ EGA data from $125-765{ }^{\circ} \mathrm{C}$ for samples before and after incubation using the NIPALS algorithm. Additionally, partial least squares regressions (PLSs) were computed, with $\mathrm{CO}_{2}$ EGA data as the explanatory variable and chemical analysis data as response variable. PLS were performed using the NIPALS algorithms along with leave-one-out cross-validation. The PLS II method was used for amino compounds, as it allows analysis of all amino groups in a single regression run, while PLS I was applied separately for carbohydrates and glucose. PLS II was particularly suited for amino groups because it allowed accounting of the strong co-linearity between amino compounds in the calculation. The $\mathrm{CO}_{2}$ EGA data were normalized for sample $C$ concentration prior to PCA and PLS analysis to reflect changes in SOM quality and not SOM quantity. PCA and PLS analyses were performed using Unscrambler 10.1 software (Camo, Norway).

\section{Results}

\subsection{Thermally evolved $\mathrm{CO}_{2}$ gas analysis}

$\mathrm{CO}_{2}$ EGA curves for all samples displayed significant qualitative differences before and after incubation, where incubated samples had a relative decrease in $\mathrm{CO}_{2}$ released between $330^{\circ} \mathrm{C}$ and $470{ }^{\circ} \mathrm{C}$ and a relative increase in $\mathrm{CO}_{2}$ released around $470{ }^{\circ} \mathrm{C}$ and $620^{\circ} \mathrm{C}$ 
(Fig. 1). PCA of these $\mathrm{CO}_{2}$ evolution curves showed that samples before and after incubation were differentiated on both PC1 and PC2 (Fig. 2). PC1 explained $90 \%$ of the total variance and was most positively correlated with $\mathrm{CO}_{2}$ released at $365^{\circ} \mathrm{C}$, but also with $\mathrm{CO}_{2}$ released at $430^{\circ} \mathrm{C}$, as indicated by the shoulder visible on PC1 loadings (Fig 2). Samples after incubation were shifted toward the left of the PCA plane vs. samples before incubation, reflecting depletion of $\mathrm{CO}_{2}$ evolved at $365^{\circ} \mathrm{C}$ during incubation. $\mathrm{PC} 2$ correlated most positively with $\mathrm{CO}_{2}$ evolved at $325^{\circ} \mathrm{C}$ and $510{ }^{\circ} \mathrm{C}$, and most negatively with $\mathrm{CO}_{2}$ evolved at $400{ }^{\circ} \mathrm{C}$. $\mathrm{PC} 2$ more clearly discriminated samples before and after incubation than PC1, but also explained less of the total variance (6\%). Samples before incubation were situated at the bottom of the PCA plane, whereas samples after incubation were situated at the top, reflecting enrichment in compounds

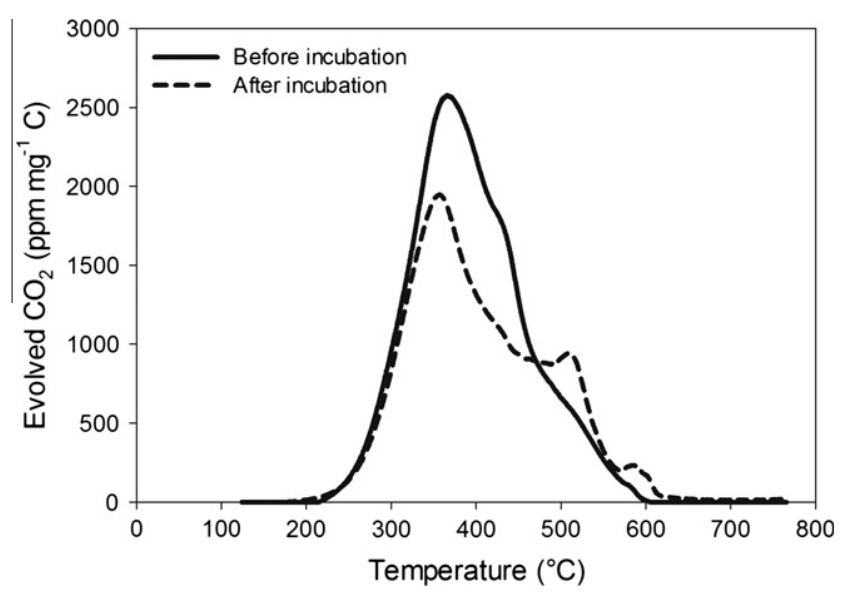

Fig. 1. $\mathrm{CO}_{2}$ release (ppm $\mathrm{mg} \mathrm{C}^{-1}$ ) during thermal analysis of a grassland soil. Changes are representative of those seen in response to incubation for all landscape elements.
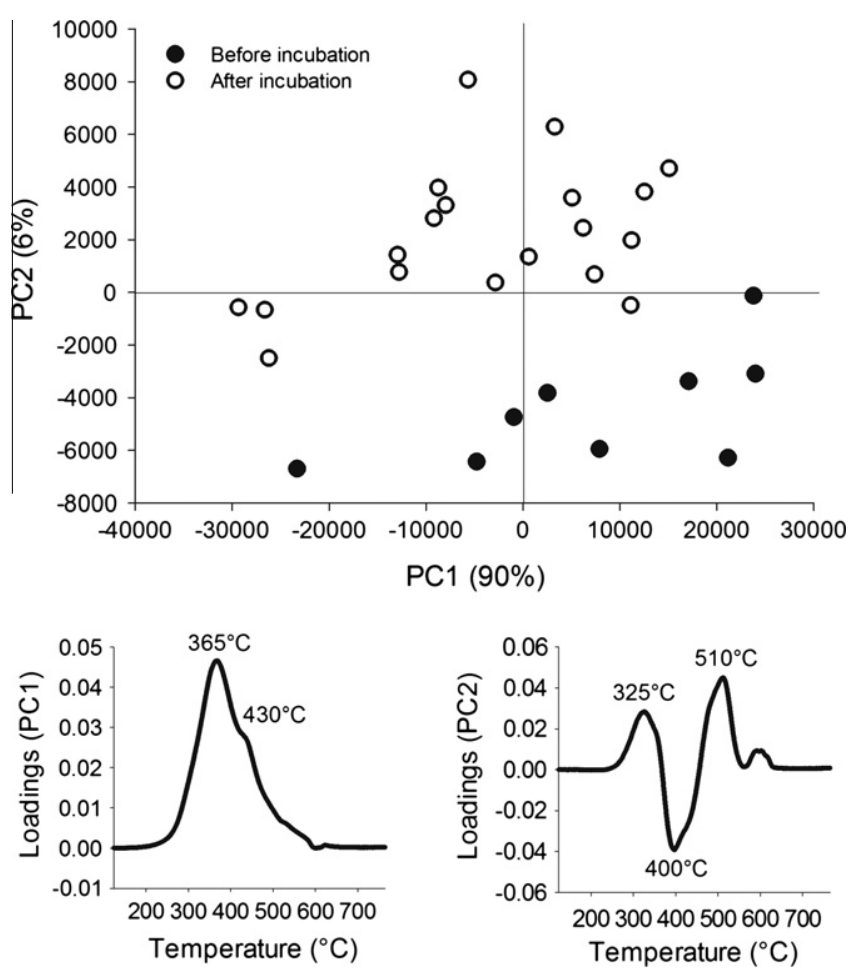

Fig. 2. $\mathrm{PCA}$ of $\mathrm{CO}_{2}$ released during thermal analysis (ppm $\mathrm{mg} \mathrm{C}^{-1}$ ). The variance explained by each PC is shown in parentheses. Loadings are shown for PC 1 and PC2. producing $\mathrm{CO}_{2}$ at $325^{\circ} \mathrm{C}$ and $510{ }^{\circ} \mathrm{C}$ and a depletion in compounds producing $\mathrm{CO}_{2}$ at around $400{ }^{\circ} \mathrm{C}$ for incubated samples.

\subsection{Biochemical analyses}

\subsubsection{Carbohydrates}

For the three landscape elements (grassland, younger woody cluster, older woody cluster) the concentration of extractable carbohydrate C dropped slightly from ca. $22 \%$ of SOC to ca. $20 \%$ of SOC after incubation. However, the loss was only significant for grassland and younger cluster soils (Table 2); the loss from older cluster soils was not significant $(P=0.30)$. Younger clusters exhibited the greatest drop in carbohydrate content, shifting from $230 \pm 38 \mathrm{mg}$ carbohydrate- $\mathrm{C} \mathrm{g}^{-1}$ SOC before incubation (the highest among the three landscape elements) to $187 \pm 33 \mathrm{mg}$ carbohydrate- $\mathrm{C}^{-1}$ SOC after incubation (the lowest post-incubation values).

Among the three landscape elements, the proportion of SOC held within total extractable carbohydrates was generally consistent for both sampling times, although small differences did exist, especially between older woody clusters and the other two landscape elements (Table 2). Generally, older woody clusters had less fucose, mannose and xylose, although only some of these relationships were significant.

Glucose, calculated as the sum of the material obtained from the mild and strong acid extractable fractions, was the largest contributor to total carbohydrates in all soils, on average comprising $38 \pm 4 \%$ of total carbohydrates prior to incubation and $36 \pm 3 \%$ after incubation. Glucose was also the only carbohydrate compound lost significantly during incubation of all samples, although there was a decreasing trend for all carbohydrate compounds except fructose. Galactose, xylose, and arabinose were lost significantly from the soils from at least one of the landscape elements: galactose was lost from the younger woody cluster and grassland soils, xylose from both woody cluster soils, and arabinose from younger woody clusters soils only. Fucose was the only carbohydrate that increased and, although it increased for all landscape elements, the increase was significant only for grassland soils.

The ratios of mannose/xylose and (galactose + mannose)/(arabinose + xylose), which are used as general markers for ratios of microbial/plant sugars (Oades, 1984; Hu et al., 1995; Glaser et al., 2000), increased significantly for younger woody cluster soils (Table 2). Increases for other landscape elements were not significant, although the increase in the mannose/xylose did show a strong increasing trend for older cluster soils $(P=0.07)$.

\subsubsection{AAs and amino sugars}

The total SOC-normalized amino content ( $\mathrm{mg}$ amino $\mathrm{C} \mathrm{g}^{-1} \mathrm{SOC}$ ) increased significantly in the grassland and younger cluster soils but remained constant in older cluster soils during incubation (Table 3). The largest increase was in the acidic AAs, whose concentration nearly doubled for grassland and younger cluster soils but increased just slightly for older cluster soils. A number of other polar and nonpolar AAs increased significantly for younger cluster and grassland soils, but many of the trends appeared to be landscape element specific. All landscape elements experienced significant increases in glycine, aspartate, and cystine and significant decreases in methionine. However, the dynamics of amino $C$ changes seemed to differ substantially between older cluster soils vs. younger cluster and grassland soils. Grassland and younger cluster soils showed increasing trends ( $\geqslant 1 \mathrm{mg}$ amino $\mathrm{Cg}$ soil $\mathrm{C}^{-1}$ ) in 13 and 19 out of 21 extracted amino compounds, respectively, of which 7 (grassland soils) and 12 (younger cluster soils) out of 21 extracted amino compounds showed a significant increase. For older cluster soils, however, only 5 out of 21 amino compounds showed an increasing trend, and only 3 of these were significant. 
Table 2

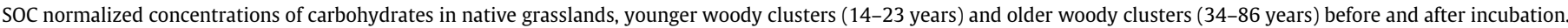

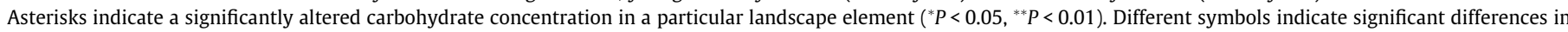
carbohydrate concentrations among the landscape elements $(P<0.05)$.

\begin{tabular}{|c|c|c|c|c|c|c|}
\hline & \multicolumn{2}{|c|}{ Grasslands (mg carbohydrate $\mathrm{Cg}^{-1} \mathrm{SOC}$ ) } & \multicolumn{2}{|c|}{ Young clusters ( $\mathrm{mg}$ carbohydrate $\mathrm{Cg}^{-1} \mathrm{SOC}$ ) } & \multicolumn{2}{|c|}{ Old clusters ( $\mathrm{mg}$ carbohydrate $\mathrm{C}^{-1} \mathrm{SOC}$} \\
\hline & Before & After & Before & After & Before & After \\
\hline Fucose & ${ }^{\dagger} 6 \pm 1.6$ & ${ }^{\dagger} 8 \pm 2.9^{*}$ & ${ }^{\dagger} 6 \pm 1.8$ & $\dagger \S_{7} \pm 2.6$ & $\S_{5} \pm 1.3$ & ${ }^{\S} 6 \pm 1.7$ \\
\hline Arabinose & $34 \pm 5$ & $+31 \pm 7$ & $38 \pm 7$ & $\dagger 31 \pm 7^{* *}$ & $36 \pm 8.6$ & $\S 38 \pm 7$ \\
\hline Rhamnose & $26 \pm 10$ & $24 \pm 11$ & $28 \pm 11$ & $23 \pm 13$ & $24 \pm 9.8$ & $24 \pm 12$ \\
\hline Galactose & $35 \pm 4$ & $30 \pm 3^{* *}$ & $38 \pm 6$ & $31 \pm 4^{* *}$ & $36 \pm 6.7$ & $34 \pm 6$ \\
\hline Mannose & $\uparrow \S 33 \pm 7$ & $30 \pm 5$ & $\dagger 37 \pm 8$ & $33 \pm 3$ & $\S 29 \pm 4.4$ & $26 \pm 5$ \\
\hline Xylose & ${ }^{\dagger} 24 \pm 4$ & ${ }^{\dagger} 21 \pm 5$ & ${ }^{\dagger} 24 \pm 5$ & $\S_{14} \pm 4^{* *}$ & $\S 17 \pm 4.8$ & $\S_{12} \pm 3^{*}$ \\
\hline Glucose $^{a}$ & $87 \pm 9$ & $74 \pm 9^{* *}$ & $86 \pm 15$ & $67 \pm 15^{*}$ & $86 \pm 22.2$ & $73 \pm 13^{*}$ \\
\hline Total carbohydrates & $227 \pm 21$ & $201 \pm 24^{*}$ & $230 \pm 38$ & $187 \pm 33^{*}$ & $216 \pm 52$ & $201 \pm 34$ \\
\hline $\mathrm{M} / \mathrm{X}^{\mathrm{b}}$ & $1.4 \pm 0.2$ & $1.5 \pm 0.5$ & $1.6 \pm 0.4$ & $2.4 \pm 0.5^{*}$ & $1.8 \pm 0.4$ & $2.4 \pm 1.2$ \\
\hline$(G+M) /(A+X)^{c}$ & $1.3 \pm 0.2$ & $1.4 \pm 0.4$ & $1.3 \pm 0.09$ & $1.6 \pm 0.3^{*}$ & $1.2 \pm 0.2$ & $1.2 \pm 0.1$ \\
\hline
\end{tabular}

${ }^{a}$ Extracted in hemicellulose and cellulose fraction.

b Mannose/xylose.

c (Galactose + mannose)/(arabinose + xylose).

Table 3

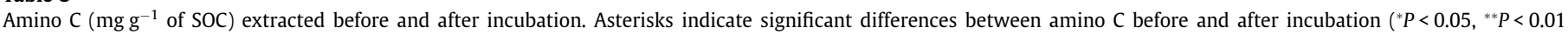
$\left.{ }^{* * *} P<0.0001\right)$.

\begin{tabular}{|c|c|c|c|c|c|c|}
\hline \multirow[t]{2}{*}{ Amino compound } & \multicolumn{2}{|c|}{ Grasslands (mg amino $\mathrm{C}^{-1}$ soil $\mathrm{C}$ ) } & \multicolumn{2}{|c|}{ Young clusters ( $\mathrm{mg}$ amino $\mathrm{Cg}^{-1}$ soil $\mathrm{C}$ ) } & \multicolumn{2}{|c|}{ Old clusters ( $\mathrm{mg}$ amino $\mathrm{C}^{-1}$ soil $\mathrm{C}$ ) } \\
\hline & Before & After & Before & After & Before & After \\
\hline Hydroxyproline & $1.3 \pm 0.5$ & $1.1 \pm 0.4$ & $2.1 \pm 0.4$ & $4.1 \pm 3.2$ & $4.1 \pm 0.8$ & $4.1 \pm 0.9$ \\
\hline Ornithine & $0.1 \pm 0.06$ & $0.2 \pm 0.1^{*}$ & $0.05 \pm 0.02$ & $0.1 \pm 0.1^{*}$ & $0.04 \pm 0.02$ & $0.04 \pm 0.04$ \\
\hline Amino sugars & $28 \pm 3.4$ & $29 \pm 4.5$ & $25 \pm 4.2$ & $33 \pm 9.7^{*}$ & $22 \pm 4.5$ & $22 \pm 4.0$ \\
\hline Galactosamine & $6.5 \pm 0.7$ & $7.2 \pm 0.8$ & $6.6 \pm 0.8$ & $9.0 \pm 2.4^{*}$ & $5.3 \pm 1.2$ & $5.5 \pm 0.9$ \\
\hline Glucosamine & $21 \pm 2.8$ & $22 \pm 3.8$ & $19 \pm 3.4$ & $24 \pm 7.5$ & $17 \pm 3.3$ & $16 \pm 3.1$ \\
\hline Acidic & $17 \pm 4.8$ & $35 \pm 13^{* *}$ & $19 \pm 8.5$ & $37 \pm 11^{* *}$ & $16 \pm 4.3$ & $19 \pm 7.6$ \\
\hline Glutamate & $7.5 \pm 2.1$ & $14 \pm 5.5^{* *}$ & $8.5 \pm 3.8$ & $15 \pm 5.3^{* *}$ & $7.8 \pm 2.0$ & $8.4 \pm 1.0$ \\
\hline Aspartate & $9.1 \pm 2.8$ & $21 \pm 7.9^{* *}$ & $10 \pm 4.8$ & $21 \pm 6.2^{* *}$ & $8.3 \pm 2.3$ & $11 \pm 4.6^{*}$ \\
\hline Basic & $26 \pm 5.1$ & $30 \pm 7.2$ & $23 \pm 6.2$ & $31 \pm 6.5^{*}$ & $19 \pm 4.4$ & $21 \pm 4.8$ \\
\hline Lysine & $6.0 \pm 1.0$ & $6.2 \pm 1.1$ & $5.6 \pm 1.0$ & $7.5 \pm 1.9^{*}$ & $5.0 \pm 1.1$ & $5.1 \pm 1.0$ \\
\hline Arginine & $17 \pm 3.7$ & $20 \pm 5.1$ & $14 \pm 4.5$ & $20 \pm 3.6^{*}$ & $11 \pm 2.6$ & $12 \pm 3.1$ \\
\hline Histidine & $3.1 \pm 0.8$ & $3.1 \pm 1.2$ & $3.3 \pm 0.9$ & $4.2 \pm 1.8$ & $3.4 \pm 0.8$ & $3.5 \pm 0.9$ \\
\hline Polar & $17 \pm 2.1$ & $20 \pm 3.3^{*}$ & $17 \pm 1.9$ & $26 \pm 7.0^{* *}$ & $18 \pm 3.2$ & $18 \pm 3.0$ \\
\hline Threonine & $6.4 \pm 0.6$ & $6.5 \pm 1.1$ & $6.7 \pm 0.6$ & $9.3 \pm 2.9^{*}$ & $6.7 \pm 1.2$ & $6.7 \pm 1.1$ \\
\hline Serine & $4.7 \pm 0.7$ & $5.1 \pm 1.0$ & $5.0 \pm 0.6$ & $7.4 \pm 2.5^{*}$ & $5.4 \pm 1.0$ & $5.5 \pm 0.9$ \\
\hline Tyrosine & $5.5 \pm 0.9$ & $8.2 \pm 1.5^{* *}$ & $5.6 \pm 0.9$ & $9.4 \pm 1.8^{* * *}$ & $5.6 \pm 1.2$ & $6.1 \pm 1.0$ \\
\hline Nonpolar & $48 \pm 5.9$ & $52 \pm 13$ & $52 \pm 5.0$ & $68 \pm 23$ & $52 \pm 9.1$ & $51 \pm 10$ \\
\hline Phenylalanine & $2.3 \pm 2.3$ & $8.5 \pm 6.0^{*}$ & $2.3 \pm 0.9$ & $4.3 \pm 4.1$ & $3.3 \pm 1.3^{* *}$ & $1.9 \pm 1.4$ \\
\hline Proline & $6.5 \pm 0.8$ & $6.1 \pm 1.0$ & $7.3 \pm 0.7$ & $10 \pm 3.4^{*}$ & $7.4 \pm 1.4$ & $7.5 \pm 1.1$ \\
\hline Alanine & $10 \pm 1.0$ & $9.5 \pm 1.8$ & $11 \pm 1.2$ & $13 \pm 4.5$ & $9.7 \pm 1.8$ & $9.8 \pm 2.2$ \\
\hline Glycine & $9.2 \pm 1.2$ & $12 \pm 2.4^{*}$ & $8.9 \pm 1.0$ & $14 \pm 2.9^{* *}$ & $7.5 \pm 1.3$ & $9.5 \pm 2.6^{* *}$ \\
\hline Valine & $8.5 \pm 2.1$ & $6.1 \pm 3.0$ & $9.0 \pm 1.5$ & $9.7 \pm 4.9$ & $8.6 \pm 1.3$ & $8.5 \pm 1.9$ \\
\hline Isoleucine & $3.6 \pm 0.5$ & $3.1 \pm 0.7$ & $4.5 \pm 0.6$ & $5.5 \pm 2.4$ & $5.0 \pm 0.9$ & $4.7 \pm 0.9$ \\
\hline Leucine & $6.7 \pm 0.9$ & $5.8 \pm 1.1$ & $7.7 \pm 0.8$ & $9.8 \pm 4.1$ & $9.1 \pm 1.5^{* *}$ & $7.8 \pm 1.3$ \\
\hline Methionine & $0.3 \pm 0.1^{*}$ & $0.18 \pm 0.07$ & $0.4 \pm 0.2$ & $0.4 \pm 0.2$ & $0.9 \pm 0.3^{* * *}$ & $0.3 \pm 0.07$ \\
\hline Cysteine & $0.7 \pm 0.2$ & $1.3 \pm 0.6^{*}$ & $0.9 \pm 0.1$ & $1.8 \pm 0.6^{* *}$ & $0.8 \pm 0.2$ & $1.1 \pm 0.3^{*}$ \\
\hline Total & $136 \pm 18$ & $167 \pm 37^{*}$ & $138 \pm 22$ & $199 \pm 56^{* *}$ & $132 \pm 25$ & $134 \pm 26$ \\
\hline
\end{tabular}

In contrast to amino $\mathrm{C}$, which increased significantly for younger cluster and grassland soils, total amino $\mathrm{N}$ increased slightly but not significantly for these landscape elements $(P=0.3$ and 0.14 , respectively). For older cluster soils, total amino $\mathrm{N}$ actually decreased significantly, predominantly through significant losses of polar and nonpolar AAs and amino sugars but also through non-significant loss of basic AAs (Table 4). Although grassland soils experienced significant losses of the nonpolar AAs proline, valine, isoleucine, leucine, and methionine, this was more than offset by a large significant increase in acidic AAs and increasing but nonsignificant trends in basic AAs and a few polar and nonpolar AAs. A similarly large $(60 \%)$ increase in acidic AAs, driven predominantly by aspartate, occurred in younger cluster soils, but these compounds remained unchanged for older cluster soils. Cystine and tyrosine also increased significantly for both younger cluster and grassland soils.

\section{Discussion}

\subsection{Contribution of carbohydrate and amino compounds to respired $\mathrm{CO}_{2}$}

Despite significantly higher SOC losses from older cluster soils $(17 \pm 3 \%)$ relative to younger cluster $(9 \pm 3 \%)$ and grassland soils $(11 \pm 2 \%)$ (Creamer et al., 2011), total carbohydrate C was not 
Table 4

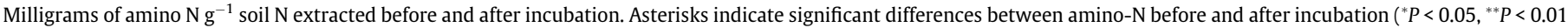
$\left.{ }^{* * *} P<0.0001\right)$.

\begin{tabular}{|c|c|c|c|c|c|c|}
\hline \multirow[t]{2}{*}{ Amino compound } & \multicolumn{2}{|c|}{ Grasslands (mg amino $\mathrm{N} \mathrm{g}^{-1}$ soil $\mathrm{N}$ ) } & \multicolumn{2}{|c|}{ Young clusters (mg amino $\mathrm{N} \mathrm{g}^{-1}$ soil $\mathrm{N}$ ) } & \multicolumn{2}{|c|}{ Old clusters ( $\mathrm{mg}$ amino $\mathrm{N} \mathrm{g} \mathrm{soil}^{-1} \mathrm{~N}$ ) } \\
\hline & Before & After & Before & After & Before & After \\
\hline Hydroxyproline & $2.9 \pm 1.1$ & $2.4 \pm 0.9$ & $4.9 \pm 1.3$ & $7.8 \pm 6.5$ & $10 \pm 1.5^{* *}$ & $8.9 \pm 2.1$ \\
\hline Ornithine & $0.5 \pm 0.3$ & $1.0 \pm 0.4^{*}$ & $0.2 \pm 0.1$ & $0.5 \pm 0.5$ & $0.2 \pm 0.1$ & $0.2 \pm 0.2$ \\
\hline Amino sugars & $52 \pm 5.1$ & $53 \pm 7.3$ & $50 \pm 9.6$ & $52 \pm 17$ & $48 \pm 10^{* *}$ & $40 \pm 6.2$ \\
\hline Galactosamine & $12 \pm 1.3$ & $13 \pm 1.5$ & $13 \pm 1.9$ & $14 \pm 4.2$ & $12 \pm 2.7^{*}$ & $10 \pm 1.4$ \\
\hline Glucosamine & $40 \pm 4.0$ & $40 \pm 6.1$ & $37 \pm 7.6$ & $38 \pm 13$ & $37 \pm 7.4^{* *}$ & $30 \pm 4.9$ \\
\hline Acidic & $43 \pm 13$ & $86 \pm 29^{* *}$ & $50 \pm 23$ & $80 \pm 29^{*}$ & $48 \pm 14$ & $47 \pm 17$ \\
\hline Glutamate & $17 \pm 5.0$ & $30 \pm 10^{* *}$ & $20 \pm 9$ & $29 \pm 11$ & $20 \pm 5.8$ & $18 \pm 7.0$ \\
\hline Aspartate & $26 \pm 8.2$ & $56 \pm 19^{* *}$ & $30 \pm 14$ & $51 \pm 17^{*}$ & $27 \pm 8.4$ & $29 \pm 11$ \\
\hline Basic & $169 \pm 31$ & $188 \pm 49$ & $155 \pm 47$ & $167 \pm 38$ & $138 \pm 33$ & $125 \pm 25$ \\
\hline Lysine & $23 \pm 3.6$ & $23 \pm 4.1$ & $22 \pm 4.3$ & $24 \pm 6.6$ & $22 \pm 4.9^{*}$ & $18 \pm 2.8$ \\
\hline Arginine & $128 \pm 27$ & $149 \pm 40$ & $113 \pm 38$ & $123 \pm 26$ & $94 \pm 23$ & $87 \pm 19$ \\
\hline Histidine & $18 \pm 4.4$ & $17 \pm 6.0$ & $19 \pm 5.7$ & $20 \pm 9.5$ & $22 \pm 5.6$ & $19 \pm 4.7$ \\
\hline Polar & $43 \pm 3.9$ & $46 \pm 7.1$ & $47 \pm 6.7$ & $55 \pm 18$ & $53 \pm 9.7^{* *}$ & $45 \pm 6.4$ \\
\hline Threonine & $18 \pm 1.2$ & $18 \pm 2.3$ & $20 \pm 2.4$ & $22 \pm 7.2$ & $22 \pm 3.7^{* *}$ & $18 \pm 2.6$ \\
\hline Serine & $18 \pm 2.0$ & $18 \pm 3.3$ & $20 \pm 3.1$ & $23 \pm 8.4$ & $24 \pm 4.3^{* *}$ & $20 \pm 3.0$ \\
\hline Tyrosine & $7.0 \pm 1.1$ & $10 \pm 1.9^{* *}$ & $7.4 \pm 1.4$ & $9.9 \pm 2.1^{*}$ & $8.1 \pm 1.8$ & $7.4 \pm 1.0$ \\
\hline Nonpolar & $153 \pm 15$ & $156 \pm 34$ & $166 \pm 21$ & $177 \pm 60$ & $175 \pm 31^{* *}$ & $146 \pm 19$ \\
\hline Phenylalanine & $3.0 \pm 2.9$ & $11 \pm 7.6^{*}$ & $2.9 \pm 1.1$ & $4.6 \pm 4.6$ & $4.7 \pm 1.8^{* * *}$ & $2.3 \pm 1.7$ \\
\hline Proline & $15 \pm 1.6^{*}$ & $13 \pm 2.2$ & $18 \pm 2.2$ & $19 \pm 6.6$ & $20 \pm 3.7^{* *}$ & $16 \pm 2.1$ \\
\hline Alanine & $39 \pm 3.7$ & $34 \pm 6.4$ & $42 \pm 6.0$ & $40 \pm 1.5$ & $42 \pm 7.9^{* *}$ & $34 \pm 4.8$ \\
\hline Glycine & $53 \pm 5.7$ & $63 \pm 12^{*}$ & $53 \pm 7.4$ & $65 \pm 15$ & $49 \pm 8.8$ & $48 \pm 5.8$ \\
\hline Valine & $20 \pm 4.8^{*}$ & $13 \pm 6.3$ & $22 \pm 4.2$ & $19 \pm 9.9$ & $22 \pm 3.5^{* *}$ & $18 \pm 3.4$ \\
\hline Isoleucine & $6.8 \pm 0.7^{*}$ & $5.6 \pm 1.3$ & $9.0 \pm 1.4$ & $8.7 \pm 4.0$ & $11 \pm 1.9^{* *}$ & $8.6 \pm 1.5$ \\
\hline Leucine & $13 \pm 1.4^{*}$ & $11 \pm 2.0$ & $15 \pm 1.9$ & $15 \pm 6.7$ & $20 \pm 3.0^{* * *}$ & $14 \pm 2.2$ \\
\hline Methionine & $0.6 \pm 0.1^{* *}$ & $0.4 \pm 0.1$ & $0.9 \pm 0.6$ & $0.7 \pm 0.4$ & $2.2 \pm 0.7^{* * *}$ & $0.7 \pm 0.2$ \\
\hline Cysteine & $2.8 \pm 0.7$ & $4.4 \pm 1.9^{*}$ & $3.6 \pm 0.7$ & $5.6 \pm 2.0^{*}$ & $3.7 \pm 1.0$ & $3.8 \pm 0.9$ \\
\hline Total & $464 \pm 62$ & $533 \pm 114$ & $474 \pm 97$ & $540 \pm 155$ & $473 \pm 9.6^{*}$ & $413 \pm 67$ \\
\hline
\end{tabular}

significantly lost from older cluster soils (Table 2) and, more importantly, the carbohydrate loss was proportionally greatest for younger clusters and grassland soils. Therefore, a higher rate of carbohydrate $\mathrm{C}$ degradation was not the reason for higher proportional $\mathrm{CO}_{2}$ losses from older woody clusters soils. In fact, assuming all decreases in soil extractable carbohydrate $C$ were mineralized to $\mathrm{CO}_{2}$, a significantly $(P<0.0001)$ smaller proportion of the respired $\mathrm{CO}_{2}$ was derived from carbohydrate $\mathrm{C}$ for older cluster soils $(12 \pm 2.8 \%)$ compared with younger cluster $(20.6 \pm 4.9 \%)$ and grassland soils $(24.9 \pm 9 \%)$. These values should be considered the maximal carbohydrate $\mathrm{C}$ contribution to $\mathrm{CO}_{2}$, since a portion of the "lost" carbohydrate $\mathrm{C}$ was likely recycled into other metabolites or rendered non-extractable. Despite these limitations, the calculation does highlight the fact that carbohydrate $C$ likely contributed less to respired $\mathrm{CO}_{2}$ for older woody cluster soils than in the other landscape elements.

As amino compound contributions to SOC remained constant in older cluster soils and increased in younger cluster and grassland soils (Table 3), it does not appear that they represented a substantial source of respired $\mathrm{CO}_{2}$ in any of the landscape elements. However, contributions from amino $\mathrm{C}$ to SOC increased to a greater extent in younger cluster and grassland soils than in older cluster soils, suggesting that the stabilization or microbial production of amino compounds differed between the landscape elements. In particular, there is the potential for greater stabilization of amino $\mathrm{C}$ on silt and clay particles in younger cluster and grassland soils as a result of the higher proportion of whole soil $\mathrm{C}$ held within this fraction (Table 1).

Interestingly, the amino $\mathrm{C}$ increases for grassland and younger cluster soils was driven predominantly by an increase in acidic AAs (glutamate and aspartate), although a number of polar and nonpolar AAs also showed significant increases in these landscape elements. Although studies have shown modest increases in aspartate during litter decomposition and sediment digenesis, glutamate is typically lost during these processes as it is assumed to be more labile (Cowie and Hedges, 1992; Dauwe and Middelburg, 1998; Keil et al., 2001; Tremblay and Benner, 2006). Aspartate and glutamate are found in higher concentration in grass tissue at this site than in woody tissue (Creamer et al., 2012) and there is a possibility that microbial access to these tissues in younger cluster and grassland soils during incubation may have resulted in some of the observed differences. Alternatively, acidic AAs can be protected through binding to $\mathrm{Al}$ or Fe oxides (Sowden et al., 1976). As a higher proportion of total soil C is held in the free silt and clay fraction in grassland and younger cluster soils than older cluster soils (Table 1 ), stabilization of acidic AAs on Fe oxides could be greater in grassland and younger cluster soils, potentially resulting in the observed relative enrichment.

\subsection{Loss of carbohydrate $C$}

The loss of bulk carbohydrate $C$ differed between the landscape elements, whereby carbohydrate $C$ was degraded either slightly faster than bulk SOC (younger clusters and grasslands) or slightly slower than bulk SOC (older clusters). The results are similar to studies that have reported a slightly slower than expected turnover of carbohydrate C (Gleixner et al., 2002), which is on par with the turnover of bulk SOC (Derrien et al., 2006). Decreased turnover of carbohydrate $\mathrm{C}$ in older cluster soils could potentially result from greater production of microbial carbohydrate $\mathrm{C}$ or from differences in carbohydrate $\mathrm{C}$ stabilization.

The turnover rate of different carbohydrate $C$ compounds can vary greatly, and carbohydrates of microbial origin are thought to be preserved to a greater extent than those of plant origin due to microbial recycling of these compounds and their greater dominance in finer soil fractions, affording them greater physical and chemical protection from degradation (Kiem and Kögel-Knabner, 2003; Nacro et al., 2004; Derrien et al., 2006). Additionally, the 
slower decay of microbial carbohydrates could be partially facilitated by their structure (e.g. glycoproteins) and their importance in binding to soil minerals (Sollins et al., 2006; Kleber et al., 2007). During incubation, there was an increase in the ratios of microbial/plant derived carbohydrates, such as mannose/xylose and (galactose + mannose)/(arabinose + xylose), for all landscape elements, although the increase was only significant for younger woody clusters (Table 2). The increase in these ratios, which can be used to indicate microbial vs. plant contributions to soil carbohydrates (Oades, 1984; Hu et al., 1995; Glaser et al., 2000), resulted from a greater loss of the plant-derived sugars (predominantly xylose) relative to galactose and mannose. This suggests there was production of microbial sugars during incubation or that carbohydrates derived from microbial biomass were preserved to a greater extent than plant-derived carbohydrates. Fucose, a microbially derived carbohydrate (Cheshire, 1979), was the only extracted carbohydrate compound that increased significantly (grassland soils only), further suggesting that microbial sugars were produced during the incubation.

\subsection{Apparent stabilization of amino $C$}

In contrast to carbohydrate $C$, amino $C$ was preserved relative to bulk SOC during the incubation as it increased for all landscape elements by $2-44 \%$ (Table 3 ), suggesting that amino compounds were either selectively preserved relative to other forms of SOC or were generated by microbial processes during incubation. Other studies have revealed the apparent stabilization of amino compounds in soil (Fan et al., 2004; Miltner et al., 2009; Knicker, 2011), often attributed to physical protection from degradation or to microbial recycling of the compounds. There is potential for amino $\mathrm{C}$ stabilization on silt and clay particles in grassland and younger woody cluster soils, although the low proportion of whole soil $\mathrm{C}$ held within this fraction in older woody cluster soils (ca. $5 \%$; Table 1 ) suggests that physical or physiochemical protection may be limited for this particular landscape element. As microbial biomass has recently been shown to contribute substantially to slowercycling SOM pools (Kiem and Kögel-Knabner, 2003; Simpson et al., 2007; Liang and Balser, 2011), there is also the possibility that amino compounds are recycled into microbial biomass and subsequently incorporated into structures that are less accessible to microbial degradation.

Amino sugars, such as glucosamine and galactosamine, are considered to be derived from microorganisms and have been used to estimate contributions from microbial biomass to SOM (Amelung, 2001; Glaser, 2004; He et al., 2011). Although there was a general increase in amino sugars during incubation, it was significant only for younger woody clusters (Table 3 ), providing evidence for the reworking of amino $\mathrm{C}$ into microbial compounds and for enhancement of amino $\mathrm{C}$ stabilization.

\subsection{Accrual of non-hydrolysable $N$ for older woody cluster soils}

In contrast to amino $\mathrm{C}$, the total amount of extractable amino $\mathrm{N}$ decreased significantly for older woody cluster soils and increased slightly but not significantly for the other landscape elements (Table 4). During incubation, total soil $\mathrm{N}$ did not change significantly for grassland soils $\left(0.56-0.51 \mathrm{mg} \mathrm{N} \mathrm{g}^{-1}\right.$ soil), young cluster soils $\left(0.80-0.76 \mathrm{mg} \mathrm{N} \mathrm{g}^{-1}\right.$ soil) or older cluster soils (1.59$1.64 \mathrm{mg} \mathrm{N} \mathrm{g}^{-1}$ soil). Therefore, either greater production of other forms of organic and inorganic $\mathrm{N}$ occurred in older woody clusters during incubation or amino $\mathrm{N}$ became less extractable by acid hydrolysis. Greater N mineralization rates have been documented in woody clusters at La Copita, although the proportion of $\mathrm{N}$ mineralized is lower in woody clusters relative to grasslands (McCulley et al., 2004). Unless the dynamics of $\mathrm{N}$ mineralization into inorganic forms was substantially altered by the incubation, this is likely not the reason for lower extractable amino $\mathrm{N}$ recovery in this study for older woody clusters after incubation. Therefore, the formation of non-hydrolysable $\mathrm{N}$ during incubation is a likely mechanism for recovery of $\mathrm{N}$ as amino $\mathrm{N}$ for older woody cluster soils. For older woodland soils, non-extractable amino-N increased from $53 \%$ to $59 \%$ of total N, while for younger cluster and grassland soils non-extractable amino $\mathrm{N}$ decreased from ca. $53 \%$ to ca. $46 \%$ of total soil $\mathrm{N}$. This non-hydrolysable $\mathrm{N}$, which in some cases has been shown to consist of heterocyclic material as well as protein (Knicker and Hatcher, 1997; Leinweber and Schulten, 1998, 2000 ), could be formed through condensation and coupling reactions of proteinaceous compounds with phenolic and polyphenolic compounds (Kraus et al., 2003; Schmidt-Rohr et al., 2004; Olk et al., 2009) or through encapsulation by hydrophobic biomolecules (Knicker and Hatcher, 1997; Knicker, 2011). In response to woody encroachment in the region, lignin and substituted fatty acids accumulate in the POM and free light fractions (Filley et al., 2008), fractions which also store the majority of accumulating $C$ (Liao et al., 2006a, 2006b) and were the dominant sources of respired $\mathrm{C}$ during incubation, and thus were substantially degraded (Creamer et al., 2011). Amino $\mathrm{N}$ in the older woody stands is therefore potentially more susceptible to conversion to non-extractable forms in older woody stands in response to incubation. This is consistent with published work for the region suggesting $\mathrm{N}$ sources in woodland soils become progressively more complex and harder to decompose as woody stands develop (Creamer et al., 2012).

\subsection{Relationship between $\mathrm{CO}_{2}$ EGA and chemical data}

The increase in SOM released at higher temperatures during thermal analysis after incubation (Fig. 1) supports the notion that thermal stability can be related to SOM stability in this system. The $\mathrm{CO}_{2}$ evolution profiles were also well-correlated with the data obtained from the amino compound analysis. Although individual peaks from thermal analysis cannot be attributed solely to the combustion of a particular compound, certain compound classes may be associated more with particular temperature regions than others (Dell'Abate et al., 2003; Strezov et al., 2004; Plante et al., 2009). PLS II analysis performed between $\mathrm{CO}_{2}$ EGA and soil $\mathrm{C}$ held in all amino groups (hydroxyproline, ornithine, amino sugars, and acidic, basic, polar and nonpolar AAs) revealed that amino compounds distinguished between incubated and unincubated soils (Fig. 3). The temperature regions of $\mathrm{CO}_{2}$ release during thermal analysis that explained $21 \%$ of the variance in amino $\mathrm{C}$ data (Fig. $3 ; 325,400,510$ and $600{ }^{\circ} \mathrm{C}$ ), were also predictive for separating incubated vs. unincubated soils (Fig. 2). Therefore, the relative increase in amino groups during incubation, as measured via acid hydrolysis (Table 3 ), was reflected in the $\mathrm{CO}_{2}$ evolution profiles of SOM during thermal analysis. Additionally, the positive correlation between amino groups and $\mathrm{CO}_{2}$ evolved at high temperature suggests these compounds were relatively stable, confirming the hypothesis that they were selectively preserved or were produced by microorganisms during incubation.

Although carbohydrate $\mathrm{C}$ was lost to the greatest extent of the compounds extracted, its correlation with $\mathrm{CO}_{2}$ EGA was not sufficient to produce a meaningful PLS regression model. However, the temperature with the largest coefficient of determination was around $365^{\circ} \mathrm{C}$ (data not shown), which interestingly decreased during incubation (Figs. 1 and 2) and has also been previously correlated with carbohydrate C loss (Dell'Abate et al., 2003). These data show that thermal analysis was able to provide a rapid assessment of SOM quality that reflected increases in amino $\mathrm{C} \mathrm{ob-}$ served during the incubation. 

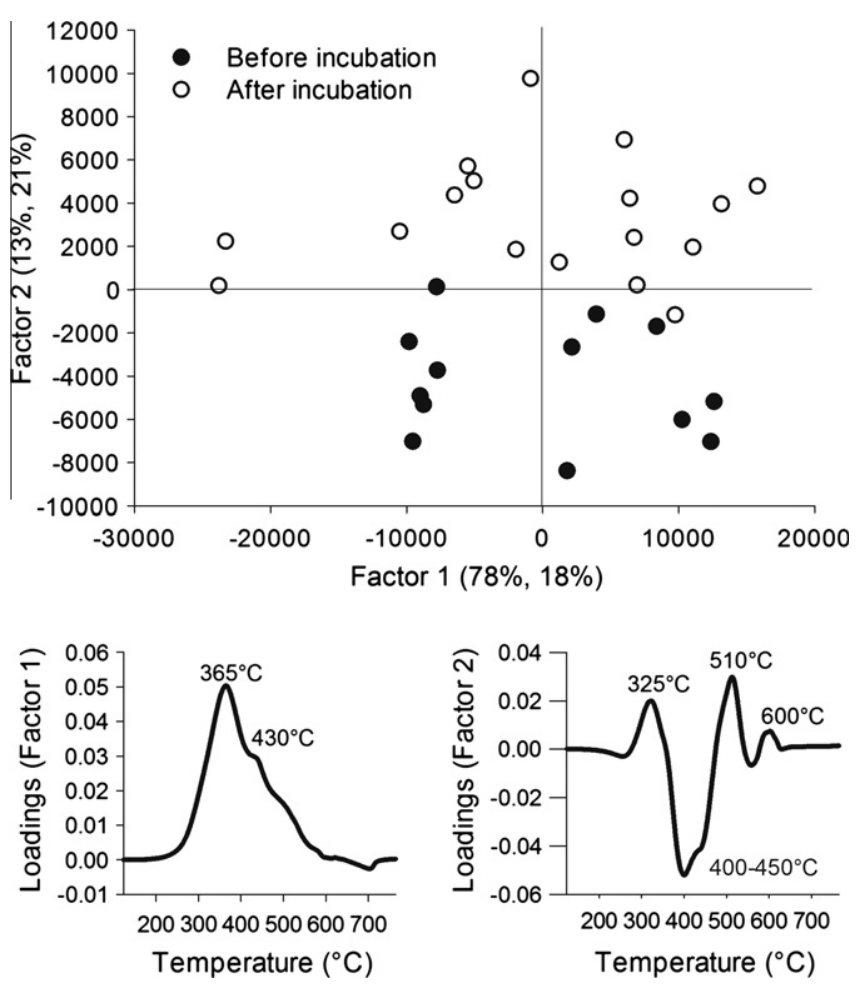

Fig. 3. Partial least squares II (PLS II) of $\mathrm{CO}_{2}$ released during thermal analysis (ppm $\mathrm{mg} \mathrm{C}^{-1}$ ) and $\mathrm{C}$ held within amino groups (hydroxyproline, amino sugars, and acidic, basic, polar and nonpolar AAs). For each factor, the proportion (\%) explained of the $X$-variance $\left(\mathrm{CO}_{2}\right.$ released during thermal analysis) and $Y$-variance (amino groups) is shown in parentheses. The PLS factors are designed to explain as much of the $Y$-variance as possible. Loadings are shown for Factors 1 and 2.

\section{Conclusions}

Due to the major role of soil organic $\mathrm{C}$ in the global $\mathrm{C}$ cycle, efforts to characterize the mechanisms that regulate the stability and turnover of this pool have intensified. However, these efforts have not yet clarified the role of SOM chemistry in SOC storage and dynamics. Changes in the abundance of amino compounds before and after incubation revealed that, in general, amino compounds will not be preferentially degraded, and will be selectively enriched or produced by microbial processes during incubation. This was confirmed from thermal analysis data, which also showed that the soils responded to incubation through an increase in SOM released at higher temperatures and a decrease in SOM released at lower temperatures.

However, the changes in SOM chemistry during incubation differed greatly between older clusters soils and younger cluster and grassland soils. Amino compounds were selectively enriched in younger cluster and grassland soils during incubation due to the loss of alternative $C$ sources or production of amino $C$ by microorganisms. Decreases in extractable amino $\mathrm{N}$ in older woody clusters suggest that, in response to woody encroachment and with enhanced decomposition, organic $\mathrm{N}$ may become more inaccessible to microorganisms. The smaller proportional loss of carbohydrate $C$ from older woody clusters confirms that the dynamics of SOM turnover are different between older woody cluster soils and younger woody cluster and grassland soils. The greater loss of plant vs. microbially-derived $\mathrm{C}$ in the landscape elements supports studies suggesting the production and recycling of carbohydrate $\mathrm{C}$ by microorganisms can aid in its persistence in soil, and that fresher plant-derived material can be utilized during incubation. Together, these data show that in these sandy loam soils, the stability of SOM during incubation was strongly driven by properties of the landscape elements (younger clusters and grasslands vs. older clusters) in addition to the less important impact of predefined notions of SOM 'lability' on its turnover.

\section{Acknowledgments}

We would like to thank D. Moore and I. Kantola for help in collecting samples, T. Grimard for guidance in amino acid, amino sugar, cellulose and hemicellulose extractions, and W. Feng for performing thermal analysis. Funding was provided by the National Science Foundation Biogeosciences Program EAR-0525349 (T.R.F. and T.W.B.) and by the USDA National Institute of Food and Agriculture 2010-65107-20351 (A.P.). We acknowledge two anonymous reviewers for comments.

\section{Associate Editor-K.G.J. Nierop}

\section{References}

Amelung, W., 2001. Methods for using amino sugars as markers for microbial residues in soil. In: Lal, R., Kimble, J.M., Follett, R.F., Stewart, B.A. (Eds.) Assessment Methods for Soil Carbon Pools. CRC/Lewis Publishers, Boca Raton, FL, pp. 233-270.

Amelung, W., Miltner, A., Zhang, X., 2001. Fate of microbial residues during litter decomposition as affected by minerals. Soil Science 166, 598-606.

Archer, S.R., 1990. Development and stability of grass/woody mosaics in a subtropical savanna parkland, Texas, USA. Journal of Biogeography 17, 453-462.

Archer, S.R., 1995. Tree-grass dynamics in a Prosopis-thornscrub savanna parkland: reconstructing the past and predicting the future. Ecoscience 2, 83-99.

Archer, S.R., Scifres, C.J., Bassham, C.R., Maggio, R., 1988. Autogenic succession in a subtropical savanna: conversion of grassland to thorn woodland. Ecological Monographs 58, 111-127.

Baldock, J.A., Skjemstad, J.O., 2000. Role of the soil matrix and minerals in protecting natural organic materials against biological attack. Organic Geochemistry 31 697-710.

Barger, N.N., Archer, S.R., Campbell, J.L., Huang, C.-ying, Morton, J.A., Knapp, A.K., 2011. Woody plant proliferation in North American drylands: a synthesis of impacts on ecosystem carbon balance. Journal of Geophysical Research 116, 17.

Blair, W.F., 1950. The biotic provinces of Texas. The Texas Journal of Science 2, 93 117.

Bond, W.J., Midgley, G.F., 2000. A proposed $\mathrm{CO}_{2}$-controlled mechanism of woody plant invasion in grasslands and savannas. Global Change Biology 6, 865-869.

Boutton, T.W., Archer, S.R., Midwood, A.J., 1999. Stable isotopes in ecosystem science: structure, function and dynamics of a subtropical savanna. Rapid Communications in Mass Spectrometry 13, 1263-1277.

Boutton, T.W., Archer, S.R., Midwood, A.J., Zitzer, S.F., Bol, R., 1998. $\Delta^{13} \mathrm{C}$ values of soil organic carbon and their use in documenting vegetation change in a subtropical savanna ecosystem. Geoderma 82, 5-41.

Boutton, T.W., Liao, J.D., 2010. Changes in soil nitrogen storage and $\delta^{15} \mathrm{~N}$ with woody plant encroachment in a subtropical savanna parkland landscape. Journal of Geophysical Research 115, G03019. http://dx.doi.org/10.1029/2009JG001184.

Cheshire, M.V., 1979. Nature and Origin of Carbohydrates in Soils. Academic Press, London, UK.

Cowie, G.L., Hedges, J.I., 1992. Sources and reactivities of amino acids in a coastal marine environment. Limnology and Oceangraphy 37, 703-724.

Creamer, C.A., Filley, T.R., Boutton, T.W., Oleynik, S., Kantola, I.B., 2011. Controls on soil carbon accumulation during woody plant encroachment: evidence from physical fractionation, soil respiration, and $\delta^{13} \mathrm{C}$ of respired $\mathrm{CO}_{2}$. Soil Biology and Biochemistry 43, 1678-1687.

Creamer, C.A., Filley, T.R., Olk, D.C., Stott, D.E., Dooling, V., Boutton, T.W., 2012 Changes to soil organic $\mathrm{N}$ dynamics with leguminous woody plant encroachment into grasslands. Biogeochemistry. http://dx.doi.org/10.1007/ s10533-012-9757-5.

Dauwe, B., Middelburg, J.J., 1998. Amino acids and hexosamines as indicators of organic matter degradation state in North Sea sediments. Limnology Oceanography 43, 782-798.

Dell'Abate, M.T., Benedetti, A., Brookes, P.C., 2003. Hyphenated techniques of thermal analysis for characterisation of soil humic substances. Journal of Separation Science 26, 433-440.

Derrien, D., Marol, C., Balabane, M., Balesdent, J., 2006. The turnover of carbohydrate carbon in a cultivated soil estimated by ${ }^{13} \mathrm{C}$ natural abundances. European Journal of Soil Science 57, 547-557.

Eldridge, D.J., Bowker, M.A., Maestre, F.T., Roger, E., Reynolds, J.F., Whitford, W.G. 2011. Impacts of shrub encroachment on ecosystem structure and functioning: towards a global synthesis. Ecology Letters 14, 709-722.

Fan, T.W.-M., Lane, A.N., Chekmenev, E., Wittebort, R.J., Higashi, R.M., 2004 Synthesis and physico-chemical properties of peptides in soil humic substances. The Journal of Peptide Research 63, 253-264. 
Filley, T.R., Boutton, T.W., Liao, J.D., Jastrow, J.D., Gamblin, D.E., 2008. Chemical changes to nonaggregated particulate soil organic matter following grasslandto-woodland transition in a subtropical savanna. Journal of Geophysical Research 113, G03009. http://dx.doi.org/10.1029/2007JG000564.

Fontaine, S., Bardoux, G., Abbadie, L., Mariotti, A., 2004. Carbon input to soil may decrease soil carbon content. Ecology Letters 7, 314-320.

Glaser, B., 2004. Amino sugars and muramic acid-biomarkers for soil microbia community structure analysis. Soil Biology and Biochemistry 36, 399-407.

Glaser, B., Turrión, M.-B., Solomon, D., Ni, A., Zech, W., 2000. Soil organic matter quantity and quality in mountain soils of the Alay Range, Kyrgyzia, affected by land use change. Biology and Fertility of Soils 31, 407-413.

Gleixner, G., Poirier, N., Bol, R., Balesdent, J., 2002. Molecular dynamics of organic matter in a cultivated soil. Organic Geochemistry 33, 357-366.

Grisi, B., Grace, C., Brookes, P.C., Benedetti, A., Dell'Abate, M.T., 1998. Temperature effects on organic matter and microbial biomass dynamics in temperate and tropical soils. Soil Biology and Biochemistry 30, 1309-1315.

Guggenberger, G., Christensen, B.T., Zech, W., 1994. Land-use effects on the composition of organic matter in particle-size separates of soil: I. Lignin and carbohydrate signature. European Journal of Soil Science 45, 449-458.

He, H., Zhang, W., Zhang, X., Xie, H., Zhuang, J., 2011. Temporal responses of soil microorganisms to substrate addition as indicated by amino sugar differentiation. Soil Biology and Biochemistry 43, 1155-1161.

Hu, S., Coleman, D.C., Hendrix, P.F., Beare, M.H., 1995. Biotic manipulation effects on soil carbohydrates and microbial biomass in a cultivated soil. Soil Biology and Biochemistry 27, 1127-1135.

Johnson, D.C., Dobberpuhl, D., Roberts, R., Vandeberg, P., 1993. Pulsed amperometric detection of carbohydrates, amines and sulfur species in ion chromatography the current state of research. Journal of Chromatography 640, 79-96.

Keil, R.G., Tsamakis, E., Hedges, J.I., 2001. Early diagenesis of particulate amino acids in marine systems. In: Goodfriend, G.A., Collins, M.J., Fogel, M.L., Macko, S.A Wehmiller, J.F. (Eds.), Perspectives in Amino Acid and Protein Geochemistry. Oxford University Press, New York, NY, pp. 69-82.

Kiem, R., Kögel-Knabner, I., 2003. Contribution of lignin and polysaccharides to the refractory carbon pool in C-depleted arable soils. Soil Biology and Biochemistry $35,101-118$

Kleber, M., Sollins, P., Sutton, R., 2007. A conceptual model of organo-mineral interactions in soils: self-assembly of organic molecular fragments into zonal structures on mineral surfaces. Biogeochemistry 85, 9-24

Knapp, A.K., Briggs, J.M., Collins, S.L., Archer, S.R., Bret-harte, M.S., Ewers, B.E., Peters, D.P., Young, D.R., Shaver, G.R., Pendall, E., Cleary, M.B., 2008. Shrub encroachment in North American grasslands: shifts in growth form dominance rapidly alters control of ecosystem carbon inputs. Global Change Biology 14, 615-623.

Knicker, H., 2011. Soil organic N - an under-rated player for $\mathrm{C}$ sequestration in soils? Soil Biology and Biochemistry 43, 1118-1129.

Knicker, H., Frund, R., Ludemann, H.-D., 1993. The chemical nature of nitrogen in native soil organic matter. Naturwissenschaften 80, 219-221.

Knicker, H., Hatcher, P.G., 1997. Survival of protein in an organic-rich sediment: possible protection by encapsulation in organic matter. Naturwissenschaften 84, 231-234.

Kraus, T.E.C., Dahlgren, R.A., Zasoski, R.J., 2003. Tannins in nutrient dynamics of forest ecosystems - a review. Plant and Soil 256, 41-66.

Köchy, M., Wilson, S.D., 2001. Nitrogen deposition and forest expansion in the northern Great Plains. Journal of Ecology 89, 807-817.

Kögel-Knabner, I., 2000. Analytical approaches for characterizing soil organic matter. Organic Geochemistry 31, 609-625.

Kögel-Knabner, I., 2002. The macromolecular organic composition of plant and microbial residues as inputs to soil organic matter. Soil Biology and Biochemistry 34, 139-162.

Leinweber, P., Schulten, H., 2000. Nonhydrolyzable forms of soil organic nitrogen: extractability and composition. Journal of Plant Nutrition and Soil Science 163 , 433-439.

Leinweber, P., Schulten, H.-R., 1998. Nonhydrolyzable organic nitrogen in soil size separates from long-term agricultural experiments. Soil Science Society of America journal 62, 383-393.

Liang, C., Balser, T.C., 2011. Microbial production of recalcitrant organic matter in global soils: implications for productivity and climate policy. Nature Reviews Microbiology 9, 75.

Liao, J.D., Boutton, T.W., Jastrow, J.D., 2006a. Storage and dynamics of carbon and nitrogen in soil physical fractions following woody plant invasion of grassland. Soil Biology and Biochemistry 38, 3184-3196.

Liao, J.D., Boutton, T.W., Jastrow, J.D., 2006b. Organic matter turnover in soil physical fractions following woody plant invasion of grassland: evidence from natural ${ }^{13} \mathrm{C}$ and ${ }^{15} \mathrm{~N}$. Soil Biology and Biochemistry 38, 3197-3210.

von Lützow, M., Kögel-Knabner, I., Ekschmitt, K., Flessa, H., Guggenberger, G., Matzner, E., Marschner, B., 2007. SOM fractionation methods: relevance to functional pools and to stabilization mechanisms. Soil Biology and Biochemistry 39, 2183-2207.

Maestre, F.T., Bowker, M.A., Puche, M.D., Belén Hinojosa, M., Martínez, I., GarcíaPalacios, P., Castillo, A.P., Soliveres, S., Luzuriaga, A.L., Sánchez, A.M., Carreira, J.A., Gallardo, A., Escudero, A., 2009. Shrub encroachment can reverse desertification in semi-arid Mediterranean grasslands. Ecology Letters 12, 930-941.
Martens, D., Frankenberger, W., 1990. Determination of saccharides by high performance anion-exchange chromatography with pulsed amperometric detection. Chromatographia 29, 7-12.

Martens, D.A., Jaynes, D.B., Colvin, T.S., Kaspar, T.C., Karlen, D.L., 2006. Soil organic nitrogen enrichment following soybean in an Iowa corn-soybean rotation. Soil Science Society of America Journal 70, 382-392.

Martens, D.A., Loeffelmann, K.L., 2002. Improved accounting of carbohydrate carbon from plants and soils. Soil Biology and Biochemistry 34, 1393-1399.

Martens, D.A., Loeffelmann, K.L., 2003. Soil amino acid composition quantified by acid hydrolysis and anion chromatography-pulsed amperometry. Journal of Agriculture and Food Chemistry 51, 6521-6529.

Martens, D.A., Reedy, T.E., Lewis, D.T., 2004. Soil organic carbon content and composition of 130-year crop, pasture and forest land-use managements. Global Change Biology 10, 65-78.

McCulley, R.L., Archer, S.R., Boutton, T.W., Hons, F.M., Zuberer, D.A., 2004. Soil respiration and nutrient cycling in wooded communities developing in grassland. Ecology 85, 2804-2817.

McLendon, T., 1993. Preliminary description of the vegetation of south Texas exclusive of coastal saline zones. Texas Journal of Science 43, 13-32.

Miltner, A., Kindler, R., Knicker, H., Richnow, H.-H., Kästner, M., 2009. Fate of microbial biomass-derived amino acids in soil and their contribution to soil organic matter. Organic Geochemistry 40, 978-985.

Nacro, H., Larre-Larrouy, M.-C., Mariotti, A., Feller, C., Abbadie, L., 2004. Natural ${ }^{15} \mathrm{~N}$ abundance and carbohydrate content and composition of organic matter particle-size fractions from a sandy soil. Biology and Fertility of Soils 40.

Oades, J., 1984. Soil organic matter and structural stability: mechanisms and implications for management. Plant and Soil 76, 319-337.

Olk, D.C., 2008. Improved analytical techniques for carbohydrates, amino compounds, and phenols: tools for understanding soil processes. Soil Science Society of America Journal 72, 1672-1682.

Olk, D.C., Anders, M.M., Filley, T.R., Isbell, C., 2009. Crop nitrogen uptake and soil phenols accumulation under continuous rice cropping in Arkansas. Soil Science Society of America Journal 73, 952.

Olk, D.C., Fortuna, A., Honeycutt, C.W., 2008. Using anion chromatography-pulsed amperometry to measure amino compounds in dairy manure-amended soils. Soil Science Society of America Journal 72, 1711-1720.

Plante, A.F., Fernández, J.M., Haddix, M.L., Steinweg, J.M., Conant, R.T., 2011. Biological, chemical and thermal indices of soil organic matter stability in four grassland soils. Soil Biology and Biochemistry 43, 1051-1058.

Plante, A.F., Fernández, J.M., Leifeld, J., 2009. Application of thermal analysis techniques in soil science. Geoderma 153, 1-10.

Poirier, N., Sohi, S.P., Gaunt, J.L., Mahieu, N., Randall, E.W., Powlson, D.S., Evershed, R.P., 2005. The chemical composition of measurable soil organic matter pools. Organic Geochemistry 36, 1174-1189.

Polley, H.W., Johnson, H.B., Mayeux, H.S., 1994. Increasing $\mathrm{CO}_{2}$ : comparative responses of the $\mathrm{C}_{4}$ grass Schizachyrium and grassland invader Prosopis. Ecology $75,976-988$.

Roques, K.G., O'Connor, T.G., Watkinson, A.R., 2001. Dynamics of shrub encroachment in an African savanna: relative influences of fire, herbivory, rainfall and density dependence. Journal of Applied Ecology 38, 268-280.

Schmidt, M.W.I., Torn, M.S., Abiven, S., Dittmar, T., Guggenberger, G., Janssens, I.A., Kleber, M., Kogel-Knabner, I., Lehmann, J., Manning, D.A.C., Nannipieri, P., Rasse, D.P., Weiner, S., Trumbore, S.E., 2011. Persistence of soil organic matter as an ecosystem property. Nature $478,49-56$

Schmidt-Rohr, K., Mao, J.-D., Olk, D.C., 2004. Nitrogen-bonded aromatics in soil organic matter and their implications for a yield decline in intensive rice cropping. Proceedings of the National Academy of Science USA 101, 6351-6354.

Scholes, R.J., Archer, S.R., 1997. Tree-grass interactions in savannas. Annual Review of Ecology and Systematics 28, 517-544.

Scifres, C.J., Koerth, B.H., 1987. Climate, Soils, and Vegetation of the La Copita Research Area. Texas Agricultural Experimental Station MP-1626, College Station, TX.

Simpson, A.J., Simpson, M.J., Smith, E., Kelleher, B.P., 2007. Microbially derived inputs to soil organic matter: are current estimates too low? Environmental Science \& Technology 41, 8070-8076.

Sollins, P., Swanston, C., Kleber, M., Filley, T., Kramer, M., Crow, S., Caldwell, B.A., Lajtha, K., Bowden, R., 2006. Organic C and N stabilization in a forest soil: evidence from sequential density fractionation. Soil Biology and Biochemistry 38, 3313-3324.

Sowden, F.J., Griffith, S.M., Schnitzer, M., 1976. The distribution of nitrogen in some highly organic tropical volcanic soils. Soil Biology and Biochemistry 8, 55-60.

Stoker, R.L., 1997. Object-Oriented, Spatially Explicit Simulation Model of Vegetation Dynamics in a South Texas Savanna. PhD Dissertation. Texas A\&M University, College Station, TX.

Strezov, V., Moghtaderi, B., Lucas, J.A., 2004. Computational calorimetric investigation of the reactions during thermal conversion of wood biomass. Biomass and Bioenergy 27, 459-465.

Tremblay, L., Benner, R., 2006. Microbial contributions to $\mathrm{N}$-immobilization and organic matter preservation in decaying plant detritus. Geochimica et Cosmochimia Acta 70, 133-146.

Van Auken, O.W., 2009. Causes and consequences of woody plant encroachment into western North American grasslands. Journal of Environmental Management 90, 2931-2942. 